\title{
Preventions of HIV/AIDS Transmission from Mother to Child in Pematangsiantar City, Indonesia
}

\author{
Dame Evalina Simangunsong ${ }^{1}$, Kandace Sianipar ${ }^{2}$ \& Juliani Purba ${ }^{2}$ \\ ${ }^{1}$ Departement of Nursing, Poltekkes Kemenkes Medan, Indonesia \\ ${ }^{2}$ Departement of Midwifery, Poltekkes Kemenkes Medan, Indonesia \\ Correspondence: Dame Evalina Simangunsong, Departement of Nursing, Poltekkes Kemenkes Medan, Jl. Jamin \\ Ginting Km 13.5 Kel Lau Cih, Kec. Medan Tuntungan, Medan, Indonesia. Tel: 81-36-243-4160. E-mail: \\ dameevalinas8@gmail.com
}

Received: July 24, 2020 Accepted: August 25, 2020 Online Published: September 10, 2020

doi:10.5539/gjhs.v12n11p83

URL: https://doi.org/10.5539/gjhs.v12n11p83

\begin{abstract}
Prevention of the HIV/AIDS transmission from mother to child should be a focus of common concern, considering that this effort is an effective and broad-impact strategy in suppressing maternal and infant mortality and is an indicator of the degree of public health in a country. Community Health Center with the Voluntary Counseling and Testing (VCT) service in Pematangsiantar has not fully provided the Prevention of Mother to Child Transmission (PMTCT). Therefore pregnant women still refuse to undergo HIV screening. In these circumstances, Pematangsiantar will potentially have an increase in the number of cases. In realizing the vision of health education institutions to integrate the promotion of HIV/AIDS and Sexually Transmitted Diseases (STD) for pregnant women, this research has studied the perception of pregnant women in the prevention of HIV/AIDS transmission from mother to child. So that the appropriate intervention strategy in suppressing the spread of HIV/AIDS can be done. The research type is quasi-experiment with the population in this study was all pregnant mothers who refused to undergo HIV screening at the time of the ANC, 194 people. Data analysis is processed with T-Test and conducted to view differences in the behavior and perception of pregnant women's beliefs against the transmission of HIV/AIDS after the intervention. The result showed there is an increased difference in the value of behavioral indicators and the health confidence of pregnant women after home visits. It is advisable to approach strategies with personal counseling, peer-Education, and home visits in the nets of pregnant women with HIV.
\end{abstract}

Keywords: health beliefs, HIV/AIDS, PMTCT, Vertical transmission

\section{Introduction}

Mother to child mortality numbers because of HIV/AIDS are both the largest provider and public health indicators determination of a country. Although various efforts have made, these were still a global health problem. These shall project numbers of social and economic issues in the future.

Prevention efforts for HIV/AIDS transmission from mother to child in Indonesia performed with the implementation of 3C (Counseling, Approval, and Confidence). 3C implemented on the Provider Initiated Testing and Counseling (PITC) program in 2010 and the Prevention of Mother to Child Transmission (PMTCT) program in 2012. However, these programs were not able to suppress the risk of transmission from mother to child. Indonesia health ministry in 2017 reported 863 housewives were suffering from AIDS, while the North Sumatera was on the seventh-ranked province with the most HIV in 2017, and from 2015 to 2017 there was an increase in HIV cases from 1891 cases, 1914 cases, and 14,891 cases (SDKI et al., 2017).

The preliminary research that performed in the working area of Pematangsiantar City Health Center in 2019, found that health workers have not provided HIV/AIDS counseling to pregnant women during an ANC (Ante Natal Care). The research found as many as 194 out of 337 pregnant women who did ANC in the period April to June 2019 were unwilling to screen HIV for various reasons such as fear and shame when knowing the positive results and prohibited husbands (Simangunsong \& Sianipar, 2020).

The socialization of PMTCT has not been performing effectively. The level of knowledge, attitude, and action (behavior) of pregnant women towards the effort to prevent the transmission of HIV/AIDS from mother to the 
child was still low. So, the stigma towards HIV/AIDS cases was still difficult to remove from society. These were assumed as the cause of the high unwillingness number of pregnant women to perform HIV/AIDS screening on ANC.

The main problem in this research is how to prevent and perception of pregnant women's belief in HIV screening in Pematangiantar City Health Center in 2019. The research aim is to analyze the behavior and perception of the beliefs of pregnant women after being given health education about HIV/AIDS prevalence efforts from mother to child with a home visit.

\section{Methods}

\subsection{Research Design}

This type of research is a research survey with a type of explanatory and quasi-experimental one-group pretest-posttest design, which aims to assess the behavioral differences and perceptions of pregnant women's beliefs against the prevention of HIV transmission from mother to child after being given health education through home visits. The research was conducted in the Pematangsiantar public health service and being implemented after the initial research in June-July 2019 and also interventions in August-September 2019.

\subsection{Population and Sample}

The population in this study was all pregnant mothers who refused to conduct HIV screening at the time of the ANC as much as 194 people.

Materials: The materials for conducting this research were Health Belief measurement Questionnaire, Pocket Books prevention efforts of HIV transmission from mother to infant.

The data on this research is sourced from primary data on the measurement of behavior (knowledge, attitudes, and actions) and perception of the pregnant mother's beliefs (vulnerability perception, seriousness perception, perception of benefits, and perception of barriers) before and after the intervention. The measurement results were analyzed analytically with the Wilcoxon test.

\subsection{Data Collection Method}

Ethical clearance for the study was obtained from the Ethics Committee Politeknik Kesehatan Kemenkes Medan.

Indicators of expectant mothers (knowledge, attitudes and actions) and Health Belief indicators of expectant mothers (susceptibility, perception of seriousness, perception of benefits and perception of barriers) after being given health education on prevention efforts of HIV transmission from mother to fetus

Research is done with the following steps:

1). Make a home visit to pregnant women who are not willing to conduct HIV/AIDS screening.

2). Conduct the collection of behavioural data (knowledge, attitudes and actions) and the perception of pregnant women's beliefs about HIV/AIDS (pretest).

3). Make a counseling about HIV/AIDS and Share the Pocket Book prevention of HIV/AIDS transmission from mother to infant.

4). Discussions on the topics that have been described and advise pregnant women to conduct screening of HIV/AIDS.

5). Screening for HIV/AIDS in pregnant mothers who are willing.

6). Re-visit the expectant mothers who have not been willing to conduct HIV/AIDS screening.

7). Conduct posttest in pregnant women who have received HIV/AIDS counseling

Data analyzed from data on behavioral measurement and the perception of the pregnant mother's beliefs before and after intervention. The measurement results were analysed analytic with Wilcoxon test.

\section{Results}

The results of the research conducted on the indicators of expectant mothers (knowledge, attitudes, and actions) and indicators of Health Belief expectant mothers (vulnerability perception, seriousness perception, perception of benefits and perception of barriers) after being given health education about the prevention efforts of HIV transmission from mother to child through the home visit, obtained the following results: 
Table 1. Frequency distribution increase knowledge category, attitude and action of pregnant women before and after the prevention of HIV/AIDS from mother to fetus

\begin{tabular}{llllll}
\hline \multirow{2}{*}{ Behavior } & Category & \multicolumn{2}{c}{ Pretest } & \multicolumn{2}{c}{ Posttest } \\
\cline { 3 - 6 } & & $\mathrm{n}(194)$ & 100 & $\mathrm{n}(194)$ & 100 \\
\hline \multirow{2}{*}{ Knowledge } & Low & 129 & 66,5 & 75 & 38,7 \\
& High & 65 & 33,5 & 119 & 61,3 \\
\hline \multirow{2}{*}{ Attitude } & Disagree & 131 & 67.5 & 37 & 19.1 \\
& Agree & 63 & 32.5 & 157 & 80.9 \\
\hline \multirow{2}{*}{ Action } & Not do & 130 & 67 & 40 & 154 \\
& Do & 64 & 33 & & 79.4 \\
\hline
\end{tabular}

The table above shows the change in the category of knowledge indicators, attitudes, and actions of pregnant women before and after the intervention of HIV/AIDS prevention from mother to child. All of the categories on this table was obtained from the answer given by the samples on pretest and posttest. Found indicators changed to positive behavior in accordance with the expected after exerted intervention.

Table 2. Increasing frequency distribution category indicator Health Belief pregnant women before and after the prevention of HIV/AIDS from mother to fetus

\begin{tabular}{llllll}
\hline \multirow{2}{*}{ Health Belief } & \multirow{2}{*}{ Category } & \multicolumn{3}{c}{ Pretest } & \multicolumn{2}{c}{ Posttest } \\
\cline { 3 - 6 } & & $\mathrm{n}(194)$ & 100 & $\mathrm{n}(194)$ & 100 \\
\hline \multirow{2}{*}{ Vulnerability perception } & Low & 185 & 95.4 & 86 & 44.3 \\
& High & 9 & 8.4 & 108 & 88.7 \\
\hline \multirow{2}{*}{ Seriousness perception } & Low & 187 & 96.4 & 91 & 46.9 \\
& High & 7 & 4.6 & 103 & 53.1 \\
\hline \multirow{2}{*}{ Benefits perception } & Low & 159 & 82 & 29 & 14.9 \\
\hline \multirow{2}{*}{ Barriers perception } & High & 35 & 18 & 165 & 85.1 \\
\hline
\end{tabular}

The table above shows the change in the category of health indicators belief expectant mothers from low to high about the vulnerability, the seriousness of the transmission of HIV/AIDS from mother to fetus and the perception of benefits and barriers to health care efforts to be obtained in connection with the transmission of HIV/AIDS from mother to fetus.

Table 3. Comparison of behavioral indicators after given health education about HIV/AIDS in Puskesmas and home visit

\begin{tabular}{llllll}
\hline \multirow{2}{*}{ Behavior } & \multicolumn{3}{l}{ Puskesmas } & Home Visit & p \\
\cline { 2 - 5 } & $($ Mean \pm SD) & Median (Min-Max) & $($ Mean \pm SD) & Median (Min-Max) & $<0.001$ \\
\hline Knowledge & $8.38 \pm 1,89$ & $8(5-12)$ & $8.97 \pm 1.71$ & $9(6-12)$ & $<0.001$ \\
\hline Attitudes & $6.80 \pm 1.39$ & $7(4-10)$ & $8.75 \pm 1,37$ & $9(6-12)$ & $<0.001$ \\
\hline Actions & $5.14 \pm 0.87$ & $5(4-7)$ & $6.60 \pm 1,23$ & $7(4-9)$ &
\end{tabular}

The table above shows there are differences in knowledge, attitudes and meaningful actions after the provision of 
health education on HIV/AIDS through home visits (test results Wilcoxon $\mathrm{p}=<0.001$ ).

Table 4. Comparison of health belief indicators after being given health education about HIV/AIDS in health service and home visit

\begin{tabular}{|c|c|c|c|c|c|}
\hline \multirow{2}{*}{ Health Belief } & \multicolumn{2}{|l|}{ Healt Service } & \multicolumn{2}{|l|}{ Home Visit } & \multirow{2}{*}{$\mathrm{p}$} \\
\hline & $($ Mean \pm SD) & Median (Min-Max) & $($ Mean \pm SD) & Median (Min-Max) & \\
\hline Vulnerability perception & $13.57 \pm 1.65$ & $13(10-18)$ & $16.84 \pm 2.60$ & $17(10-22)$ & $<0.001$ \\
\hline Seriousness perception & $13.59 \pm 1.6$ & $14(10-18)$ & $16.71 \pm 2.97$ & $17(10-25$ & $<0.001$ \\
\hline Benefits perception & $12.17 \pm 1.76$ & $12(9-18)$ & $16.33 \pm 2.71$ & $17(10-23)$ & $<0.001$ \\
\hline Barriers perception & $12.02 \pm 1.5$ & $12(8-16)$ & $14.73 \pm 2.17$ & $15(10-20)$ & $<0.001$ \\
\hline
\end{tabular}

The table above shows that there are differences in vulnerability perception, seriousness, benefits and meaningful barriers after the provision of health education on HIV/AIDS through home visits (Wilcoxon $\mathrm{p}$ Test results $=<$ $0.001)$.

\section{Discussion}

Health Belief Model is the main concept of healthy behavior that is determined by the individual belief or perception that is believed by the individual about the severe or absence of a disease, the risk or absence of individuals affected by diseases and facilities available to get countermeasures and avoid the occurrence of a disease. This Model can demonstrate how the public responds to the symptoms of the disease and how their behavior is against diagnosed diseases, especially those associated with treatment actions as an effort to counteract the disease.

To date, this model has become one of the most influential models and has been widely used in the psychosocial approach to explaining the relationship between behavior with health. This Model specifies how individuals are cognitive to demonstrate healthy behavior as well as efforts to healthy or cure a disease based on the beliefs or beliefs of individuals about healthy behaviors or certain medications that can make themselves healthy or cured.

The results of this study showed that there is a difference in the health belief indicator of pregnant women before giving health information about the prevention of HIV transmission from mother to child through home visits. HBM component changes show significant results so that health education is a factor that affects one's belief in the desired health behavior. Factors of belief in cognitive-based health proved to be related to thought processes so that individuals want and able to make decisions in determining a healthy way of life.

The intervention given to expectant mothers is done through home visits. The socialization of the prevention of HIV/AIDS transmission from mother to child is done using Pocket Book media and leaflets. The results showed a change in perception of the health belief component of pregnant women about the prevention efforts of HIV/AIDS transmission from mother to fetus. Changing the perception of the mother in the better direction suggests that pregnant women can receive a given intervention coupled with the presence of media given to the mother, the home visits made make the mother more comfortable and open in asking questions about the topics discussed. The results showed there was a difference in the average Health Belief score increase after the home visit $(\mathrm{p}<0.001)$.

Indicators of vulnerability perception of expectant mothers change home visits and are given an approach by providing health information about the preventive efforts and prevention of HIV/AIDS transmission from mother to child. This situation shows the cognitive process in receiving the stimulus in the form of health information about the prevention and transmission of HIV/AIDS from mothers can suppress the increase in morbidity and mortality of HIV/AIDS in the mother and infant. A total of $88.7 \%$ of pregnant mothers who have obtained information with a home visit have had a good perception of the vulnerability, so it can predict the success of preventive efforts as well as health maintenance efforts to the transmission of the virus.

Similarly, changes to the indicators of perceptual perception, as much as $53.1 \%$ of pregnant women have changed the perception of the seriousness in the direction of the better. Respondents have known and understood that the transmission of HIV/AIDS from mother to infant can result in very poor conditions until death. If a pregnant mother has been detected HIV, it is necessary to do a protection effort by controlling the viral load in his body as low as possible, so as not to transmit it on his entry. Pregnant women with HIV need to immediately get ARV to 
protect themselves from falling under the heavier state of AIDS and the babies they contain are not infected by HIV (Kemenkes, 2011).

The better perception of the seriousness of the problem can be predicted that health care efforts will also be better, to avoid getting health problems. The knowledge of the worse health disorders that will be faced can make individuals change and make preventive efforts to avoid fearful health problems. Perception of severity relates to individual beliefs or beliefs about the seriousness or severity of the disease. Seriousness perception is often based on medical information or knowledge, it can also come from a person's belief that he will have difficulties due to illness and will make or effect on his life in general.

The change in indicators of the perception of benefits expressed by expectant mothers has a better direction of $85 \%$. The perception of an individual's perceived benefit refers to a person's judgment of strength to reduce the risk of getting worse an illness. The perception of benefits expressed by respondents will strengthen it in the prevention of HIV transmission and prevention efforts of the fetus that it contains.

Changing indicators of the perception of obstacles expressed by expectant mothers, undergoing a good change after home visits.

It shows a statement of negative and conflicting aspects for a precaution. Clear health information has been able to increase the insight of expectant mothers to health conditions that will be experienced and the health care efforts to be undertaken. Barriers are characteristic of measuring a preventive effort. If the effort to be costly, difficult, and unpleasant, it can cause someone to avoid the effort.

The perception of high barriers can also be caused by anxiety to stigma and discrimination in communities including by healthcare personnel and access to obtaining HIV test services. Stigma and discrimination against ODHA impact on HIV prevention efforts, individuals will refuse to conduct HIV test because it is not ready to accept stigma and discrimination when positive results (Chi et al., 2012).

The Health Belief theory states that individuals will take treatment or prevention actions if they feel greater threats. Similarly, a high perception of HIV/AIDS will cause individuals to make preventive or early detection efforts against the disease. Obstacle perception is a person's judgment of the magnitude of the obstacle to adopt or take the recommended action. An action may not be taken by a person, even if the individual believes in the benefit of taking that action (Rosenstock \& Strecher, 1988).

The perception of obstacles in pregnant women can also come from stigma and discrimination from various parties. Stigma and discrimination, are two things that affect the obstacles in implementing the test related programs for HIV/AIDS, so it will reduce the use of health services.

Priyoto (2014), to the right, that the perception of obstacles is a meaningful element in determining the occurrence of behavioral changes. Individuals should believe that the benefits of the new behavior are greater than the consequences of continuing the old behavior.

Individual perception of the vulnerability and severity of illness resulted in a perception of how much the threat of disease occurred against it. Consideration of the gains gained from expected behavior and consideration of the surrounding environment will be the basis of consideration in approving expected behavior. To the end, the individual may decide to behave cues to action due to the signs or symptoms of themselves or others; Information, both from mass media and healthcare personnel; The support of the family (Sallis \& Owen, 2008).

Each individual has a different way of taking the action of healing or prevention in addressing health problems, which depends on his desire for access to health care and related to the knowledge and opinions of others about the health problems experienced (Notoatmodjo, 2011). The results of the research conducted by Wenny et al, there is an influence of information exposure, both from health officers, print media, and electronic media in conducting HIV tests. High knowledge, vulnerability perception, seriousness, and high benefits affect the behavior of conducting HIV tests (Wenny et al., 2016).

The Health theory belief model states that someone will act on medication or prevention when encouraged by the threat of illness. They believe that HIV is a serious disease that will be discouraged by people and HIV-infected babies have a chance to live smaller than adults. Threats with the symptoms of the disease will make the individual seek medical help.

\section{Conclusion}

The intervention carried out on the socialization of prevention efforts of HIV/AIDS transmission from mother to child using leaflets Media and pocket Book with a method of personal counseling approach through home visits and class visits pregnant women, indicating the presence of behavior change and perception of a better belief in 
expectant mothers. Not all health officers in the Public health center in the city of Pematangsiantar approach pregnant women as an effort to empower in screening HIV/AIDS

\section{Competing Interests Statement}

The authors declare that there are no competing or potential conflicts of interest.

\section{References}

Chi, B. H., Adler, M. R., Bolu, O., Mbori-Ngacha, D., Ekouevi, D. K., Gieselman, A., ... \& Mofenson, L. M. (2012). Progress, challenges, and new opportunities for the prevention of mother-to-child transmission of HIV under the US President's Emergency Plan for AIDS Relief. JAIDS Journal of Acquired Immune Deficiency Syndromes, 60, S78-S87. https://doi.org/10.4103/0972-124X.92576

Kemenkes, R. I. (2011). Pedoman Nasional Pencegahan Penularan HIV dari Ibu ke Anak (PPIA). Journal of Indian Society of Periodontology. https://doi.org/10.4103/0972-124X.92576

Kemenkes, R. I. (2016). Program Pengendalian HIV AIDS dan PIMS di Fasilitas Kesehatan Tingkat Pertama: Petunjuk Teknis. Direktorat Jenderal Pencegahan Dan Pengendalian Penyakit.Notoatmodjo, S. (2011). Kesehatan Masyarakat Ilmu \& Seni. In Rineka Cipta.

Notoatmodjo, S. (2011). Kesehatan Masyarakat Ilmu \& Seni. In Rineka Cipta.

Rosenstock, I. M., \& Strecher, V. J. B. M. (1988). The Health Belief Model and Preventive Health Behavior. Health Education Quarterly. https://doi.org/10.1177/109019818801500203

Sallis, J. F., \& Owen, N. F. E. (2008). Social and Behavioral Theories. Health Behavior and Health Education: Theory, Research, and Practice. https://doi.org/10.1146/annurev.publhealth.012809.103604

Samaran, E., Shaluhiyah, Z., \& Sriatmi, A. (2013). Implementation Screening Program of the "Prevention of Mother to Child Transmission of HIV" (PMTCT) by Midwives in Health Center at Sorong West Papua. Journal Manajemen Kesehatan Indonesia. https://doi.org/10.14710/JMKI.1.3.2013.\%P

SDKI, BKKBN, BPS, Kemenkes, \& USAID. (2017). Survey Demografi dan Kesehatan Indonesia 2017. In Survey Demografi dan Kesehatan Indonesia 2017. https://doi.org/10.1111/j.1471-0528.2007.01580.x

Simangunsong, D. E., \& Sianipar, K. P. J. (2020). Perilaku dan Persepsi Keyakinan Ibu Hamil Terhadap Screening HIV di Kota Pematangsiantar. Jurnal Penelitian Kesehatan "SUARA FORIKES" (Journal of Health Research" Forikes Voice"), 11(2), 202-207. https://doi.org/10.33846/sf.v11i2.759

Wenny, D. M., Subronto, Y. W., \& Hakimi, M. (2016). Faktor yang Mempengaruhi Perilaku Ibu Hamil Melakukan Tes HIV di Puskesmas Kota Yogyakarta. Berita Kedokteran Masyarakat. https://doi.org/10.22146/bkm.11326

Widiati, E. (2019). Efektivitas Konseling Dan Tes Hiv (KTHIV) Berdasarkan Permenkes Nomor 21 Tahun 2013 Tentang Penanggulangan HIV Dan AIDS Di Puskesmas Kabupaten Cilacap. Jurnal Idea Hukum. https://doi.org/10.20884/1.jih.2018.4.1.67

\section{Copyrights}

Copyright for this article is retained by the author(s), with first publication rights granted to the journal.

This is an open-access article distributed under the terms and conditions of the Creative Commons Attribution license (http://creativecommons.org/licenses/by/4.0/). 